Article

\title{
Household Livelihood Strategy Choices, Impact Factors, and Environmental Consequences in Miyun Reservoir Watershed, China
}

\author{
Wenjia Peng ${ }^{1}$, Hua Zheng ${ }^{1, *}$, Brian E. Robinson ${ }^{2}$, Cong $\mathrm{Li}^{3}$ and Fengchun Wang ${ }^{4}$ \\ 1 State Key Laboratory of Urban and Regional Ecology, Research Center for Eco-Environmental Sciences, \\ Chinese Academy of Sciences, Beijing 100085, China; pwj1992@126.com \\ 2 Department of Geography, McGill University, Montreal, QC H3A 0B9, Canada; brian.e.robinson@mcgill.ca \\ 3 School of Economics and Finance, Xi'an Jiaotong University, Xi'an 710061, China; liconglc@mail.xjtu.edu.cn \\ 4 Beijing Water Science and Technology Institute, Beijing 100044, China; wangfengchun813@163.com \\ * Correspondence: zhenghua@rcees.ac.cn; Tel.: +86-10-6284-9815
}

Academic Editors: Phoebe Koundouri and Ebun Akinsete

Received: 5 December 2016; Accepted: 18 January 2017; Published: 25 January 2017

\begin{abstract}
Household livelihood strategies are embedded in the natural and socioeconomic contexts in which people live. Analyzing the factors that influence household livelihood choice and defining their consequences can be beneficial for informing rural household policies. In turn, this has great significance for fostering sustainable livelihood strategies. We grouped household livelihood strategies based on the income distribution of 756 households and analyzed their influencing factors and possible livelihood consequences in the watershed of Miyun Reservoir, the only source of surface water currently available for domestic use in Beijing, China. Local farmers' livelihood strategies can be grouped into three types: farming, local off-farm, and labor-migrant. Farming households have the lowest livelihood capitals, other than natural capital, compared with labor-migrant households and off-farm households, the latter having better livelihood capital status. Geographical location, natural capital, household structure, labor quality, and ecological policies are the main factors affecting farmers' choice of livelihood strategy. Local off-farm households have a significantly lower dependency on firewood, land resources, and investment than that of farming and labor-migrant households, and have the highest reliance on fossil fuel. This household classification can help us understand the livelihood characteristics, impact factors, and consequences of different types of household strategies, which also suggest tailored policy and management options to promote sustainable livelihoods based on different household types.
\end{abstract}

Keywords: agricultural households; livelihood strategy; livelihood diversity; watershed management; China

\section{Introduction}

Rural poverty and environmental degradation are two intertwined challenges developing countries are facing. How to improve rural household livelihoods, and simultaneously realize ecological conservation in rural areas, has become a common concern of global social organizations, and an area of increasing research [1]. In recent years, scholarship on the relationship between agrarian livelihoods and the environment has grown in quantity and sophistication [1-4]. Livelihood strategies is a term that comprises the range and combination of activities and choices that people make in order to achieve their livelihood goals, including production activities, investment strategies, and reproduction arrangements [5]. Household and individual livelihood strategies are closely related to the natural and socioeconomic contexts in which people live, and can determine the efficiency of 
natural resource use, as well as the means and intensity of environmental interference [6]. Researches on rural household livelihood strategies, particularly on the types of strategies that rural households typically adopt and the factors that shape these strategies, have contributed to our understanding of the relationships between rural household livelihoods and the natural environment. Understanding these relationships has important implications for realizing a win-win for rural environmental protection and rural household livelihood improvement.

Previous studies of rural household livelihood strategies have tended to divide households into categories on the basis of household income derived from different activities [7-9], or on the basis of asset use and labor distribution [10,11]. However, household and individual livelihood strategies are not fully-described only by income, asset use, or labor. These are also determined by the diversity of the households' assets (tangible resources like physical, financial, or natural capital, and intangible ones like social and human capital), as well as the social institutions that govern how or whether one has access to assets [12-18]. Therefore, livelihoods are not merely a summary measure of cash-equivalent resources, but are complex, multidimensional, and closely related to the natural and socioeconomic contexts in which people live [19-21]. In this study we recognize all these factors underpin livelihood dynamics, and we use a variety of measures from our own field collected data to categorize different livelihood types in an effort to try to better capture these issues. In addition, most studies on household livelihood strategies are mainly focused on community or local scales, with few studies defining strategy types and their influencing factors within specific management units, such as the watershed scale as is the case we present here.

We investigated the watershed of the Miyun Reservoir, the only source of surface water currently available for domestic use in Beijing, China. Ecosystem services (e.g., water provision, soil retention, water purification) in the watershed are extremely important for water conservation. The watershed crosses two administrative regions, Hebei Province and Beijing, which represent a large variation in resource endowments, economic and social conditions, living standards, and rural household livelihood activities. In this area, rural household livelihoods are gradually transitioning from traditional agriculture to more diversified strategies. Consequently, there have been changes observed in livelihood consequences, including dependence on natural resources, the ways in which land resources are utilized and the efficiency of their use, and household welfare, amongst other factors. We adopted a stratified sampling method, using data from a household survey based on participatory rural appraisal. We then identified household livelihood strategies through factor and cluster analyses based on distribution of income, and explained the influencing factors of different types of livelihood strategies and their livelihoods consequences. We aimed to classify household livelihood strategy choices and understand their livelihood characteristics, impact factors, and possible livelihood consequences. Finally, we hope to provide tailored policy and management options to promote sustainable livelihoods based on our findings.

\section{Conceptual Framework}

To provide the conceptual and theoretical foundations of this study, we present a conceptual framework (Figure 1) for household livelihood sustainability analysis based on the sustainable rural livelihood framework [21]. Natural (e.g., geographical location, resource endowment, etc.) and socioeconomic (e.g., market fluctuations, education level, policy background, etc.) contexts influence household decisions to engage in various livelihood strategies (e.g., farming, local off-farm or labor-migrant) [6,22-25]. Subsequently, different strategies can result in different livelihood outcomes (including security, basic material for good life, health, and environmental quality) through changes in livelihood assets, income, energy utilization, land use, outmigration, etc. These outcomes impact the overall sustainability of a livelihood portfolio. In light of these different livelihood consequences and contexts, policy makers try to improve the sustainability of household livelihood outcomes through policy innovation (e.g., eco-compensation, infrastructure construction, educational investment) [26-30]. Here, we first classify household livelihood strategy choices and then examine factors that impact 
different types of livelihood strategies and their possible livelihood consequences based on our data. Finally, we provide tailored policy and management options with the goal of promoting more sustainable livelihood options based on the above findings.

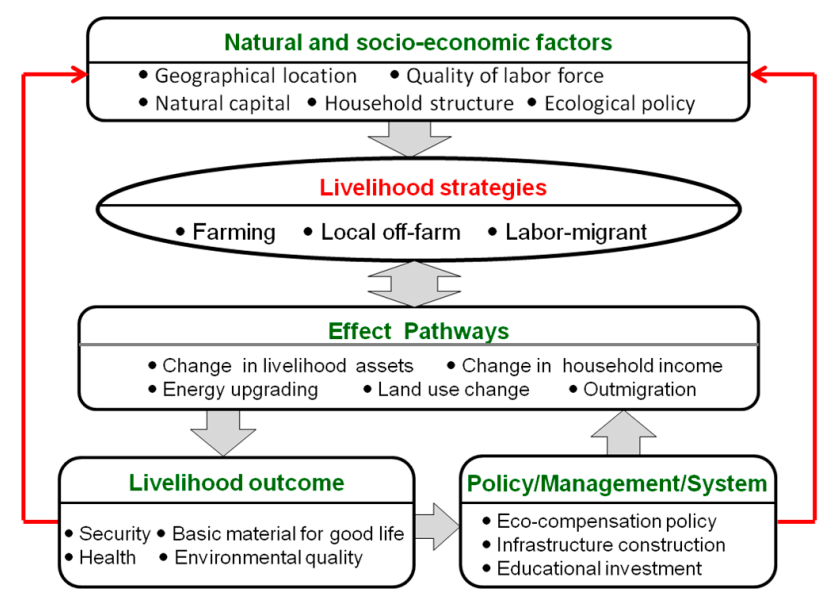

Figure 1. Conceptual framework of household livelihood strategies and livelihood outcomes.

\section{Study Area and Methods}

\subsection{Study Area}

The study was conducted in the Miyun Reservoir Watershed $\left(40^{\circ} 19^{\prime}-41^{\circ} 38^{\prime} \mathrm{N}, 115^{\circ} 25^{\prime}-117^{\circ} 35^{\prime} \mathrm{E}\right)$, which is located about $100 \mathrm{~km}$ north of Beijing, China (Figure 2) and is the major surface water source for Beijing with a total area of approximately 1.52 square kilometers. The terrain is high in the northwest, with the mountains rising to between approximately $1000 \mathrm{~m}$ and $2300 \mathrm{~m}$, and low in the southeast, composed mainly of hills and a few plains and floodlands.

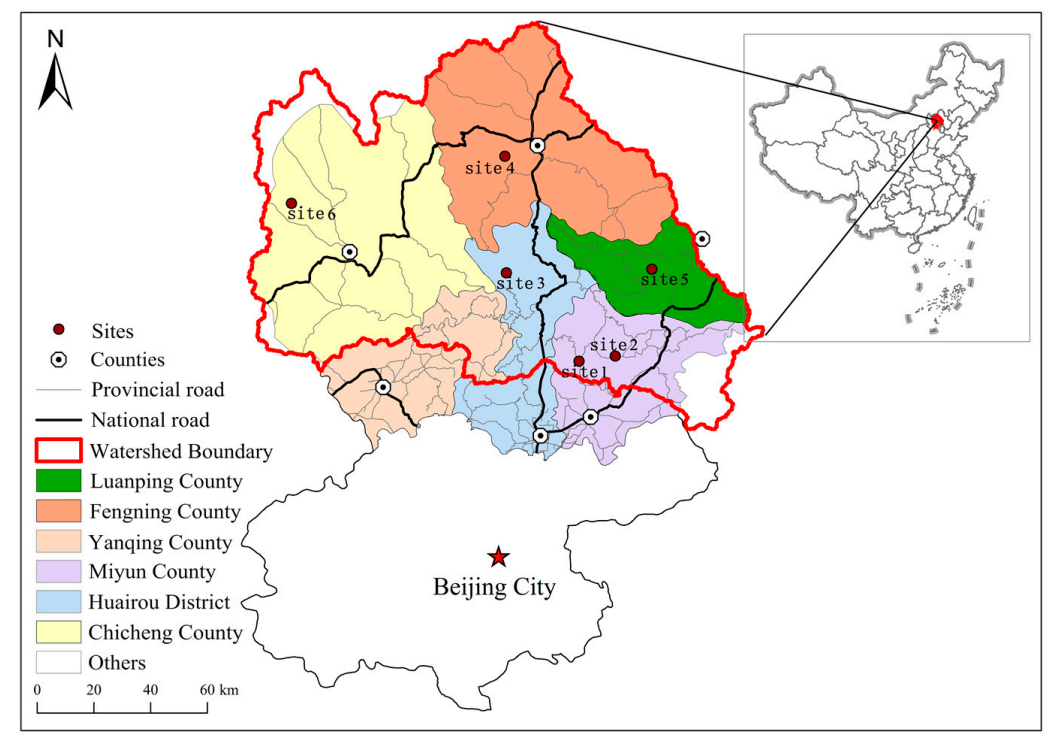

Figure 2. Distribution of household survey samples and county boundaries of the study area in the Miyun Reservoir Watershed.

The Miyun Reservoir Watershed crosses two administrative regions: Hebei Province and Beijing. About four-fifths of the watershed is located in Hebei Province with the remaining one-fifth in the greater municipality of Beijing (Figure 2). The watershed is, therefore, affected by many factors such as 
geographical location and natural environment conditions, and there are large variations in the level of living standards and rural household livelihood activities across the area. The average net income of farmers in the Beijing townships is about three times that found in the Hebei Province [30].

\subsection{Data Collection}

Data were collected from detailed household surveys fielded in August 2014 in the upstream watershed of the Miyun Reservoir. Participatory rural appraisal and multistage stratified cluster sampling were used in the investigation. The survey participants were distributed across five counties, different distances away from Beijing city. In each county, we selected 1-2 townships that represented the average standard of living of the county; in each township, we selected one village that represented the average standard of living of the township. Ultimately, we selected six villages among the five counties as our survey samples. To capture spatial and jurisdictional differences, two villages were selected within Miyun County in Beijing. House to house surveys were conducted in these six villages, according to the total number of households in each village. We worked with a large team of 8-10 people, spent two to three days and surveyed between 101 and 147 households per village (accounting for approximately $35 \%$ of the total number of households in each village), attempting to survey all households available. We carried out in-depth interviews with household members using semi-structured questionnaires. In total, 756 valid questionnaires were obtained. The questionnaire survey mainly focused on sociodemographic information of household members and their livelihood activities, agriculture investments and outputs, household incomes and expenditures, and energy consumption. We predominantly selected household heads as interviewees, as they were usually the household decision makers and knew the key information about the family. We also verified summaries of our data with village leaders to ensure reliability and accuracy of data.

\subsection{Data Analyses}

Against the backdrop of large-scale urbanization and rapid economic growth, traditional farming is no longer the only way rural residents can make a living; they are often faced with diverse and abundant livelihood activities from which they may choose. To investigate livelihood strategies and determinants, we conducted three stages of analysis.

First, given the key role of the source of household income and labor force allocation in understanding its livelihood strategy, we used factor analysis to reduce the number of dimensions though which these factors are used to explain household livelihood strategies. According to whether the eigenvalues are greater than 1 , we extracted three comprehensive factor dimensions from seven variables that describe the source of livelihoods, which explained $62.06 \%$ of the variability in rural household livelihood strategies. The variables we included in the cluster analysis were:

(1) Total income: the sum of incomes that all family members earned, including wage income, operational income, property income, and transfer income;

(2) Agricultural income: the income that farmers obtained by farming, operating orchards, and breeding livestock;

(3) Tourism income: the income that family members obtained from other service industries such as tourism, hospitality, and entertainment;

(4) Agri-business income: income generated by family members engaged in the processing of agricultural products (e.g., rice milling, oil pressing, and medicinal materials processing), agricultural services (e.g., irrigation and grain reaping), commerce, and repair services;

(5) Other local non-farm income: income generated by family members engaged in transportation, construction projects, and other industrial or manual labor as well as education, health, and government departments;

(6) Remittance income: income sent home by migrant workers;

(7) Moving out for work: whether family members had moved out for work or not. 
Next, we used k-means cluster analysis to classify all samples and define clusters of household livelihood strategy types. Considering the livelihood activities in the study area, we identified livelihood strategies by clustering households based on the share of household income generated by different livelihood activities and household members' migration for work.

Third, after determining livelihood strategy groups, we used a multinomial logistic model to analyze determinants of livelihoods strategies. The model simulated the farmers' livelihood strategy choice based on the strategy that maximized their own effectiveness, i.e., that ensured the maximum benefit to households. The probability calculation of farmers to choose a specific livelihood strategy was:

$$
\begin{gathered}
\operatorname{Prob}\left(Y_{i}=j\right)=\frac{e^{x_{i}^{j} B_{i j}}}{1+\sum_{k=0}^{m} e^{x_{i}^{j} B_{i j}}}=F_{j}\left(X_{i}, B\right) \\
j=0,1,2, \ldots, m ; i=1,2,3, \ldots, N \text { and } B_{0}=0
\end{gathered}
$$

where, $\operatorname{Prob}\left(Y_{i}=j\right)$ represents the probability of household $i$ choosing livelihood strategy $j$ out of $m$ strategies, $x_{i}^{j}$ represents the factors that influence household livelihood strategy selection, $B_{i j}$ represents the corresponding parameters of the model to be estimated. The model selected nine independent variables that reflect five general aspects that influence household livelihood strategies: geographical location, natural capital, household structure, labor quality, and ecological policy [15]. The independent variables were land area, household size, skills training, skill, the average age of household laborers, the average education level of laborers, amount paid from the ecological compensation funds, the distance from Beijing city, and the distance from the local county capital city. As can be seen, these factors are not just measures of income, but also relate to the local social, institutional, and ecological contexts in which household livelihood decisions are embedded.

Rural households' livelihood behavior can ultimately influence the quality of the rural environment through the utilization of natural resources. Finally, in order to compare differences in the extent of natural resource utilization between different households, we selected the following independent variables to measure the households' land resource utilization and energy utilization: crop yield per $m u(1 \mathrm{mu}=1 / 15 \mathrm{ha})$, expenditure on fertilizers and pesticides, and consumption of firewood, coal, liquefied petroleum gas, and electricity. Statistically significant differences were analyzed using one-way ANOVA with the software stata13.

\section{Results}

\subsection{Household Livelihood Strategy Classification}

Factor 1 was significantly positively correlated with total income and choices of outmigration for work. Factor 2 was significantly positively correlated with tourism revenues, while factor 3 was significantly positively correlated with agriculture revenues (Table 1). Household livelihood strategies, therefore, can be divided into three patterns: farming, local off-farm, and labor-migrant. Among the 756 peasant households, the three patterns account for $56.7 \%, 13.1 \%$, and $30.2 \%$ of the total, respectively.

Table 1. Extracted factors of household livelihood and correlation with original variables.

\begin{tabular}{cccc}
\hline Variables & Factor $\mathbf{1}$ & Factor 2 & Factor 3 \\
\hline Agricultural income & 0.12 & -0.10 & 0.90 \\
Tourism income & 0.54 & 0.54 & -0.20 \\
Agri-business income & 0.32 & 0.33 & -0.21 \\
Other local non-farm income & 0.28 & 0.44 & 0.33 \\
Remittance income & 0.61 & -0.57 & -0.04 \\
Moving out for work migrating & 0.47 & -0.66 & -0.13 \\
Total income & 0.92 & 0.17 & 0.06 \\
\hline
\end{tabular}


The three types of household incomes present obviously different characteristics (Table 2). Agricultural income in farming households was significantly higher than that of the other two types, accounting for $51.19 \%$ of the total income. In addition, the local non-farming incomes of local off-farm households was significantly higher than that of the other two types of households, accounting for $55.87 \%$ of the total income. The remittances of labor-migrant households were significantly higher than the other two types of households, accounting for $51.16 \%$ of the total income.

Table 2. Income composition of different household livelihood strategies.

\begin{tabular}{|c|c|c|c|c|c|c|}
\hline \multirow{4}{*}{ Variables } & \multicolumn{6}{|c|}{ Livelihood Strategy } \\
\hline & \multirow{2}{*}{\multicolumn{2}{|c|}{$\begin{array}{c}\text { a. Farming } \\
(N=429)\end{array}$}} & \multirow{2}{*}{\multicolumn{2}{|c|}{$\begin{array}{c}\text { b. Local Off-Farm } \\
(N=99)\end{array}$}} & \multirow{2}{*}{\multicolumn{2}{|c|}{$\begin{array}{c}\text { c. Labor-Migrant } \\
(N=228)\end{array}$}} \\
\hline & & & & & & \\
\hline & Mean & SD & Mean & SD & Mean & SD \\
\hline Farming income (\%) & $51.19^{b, c}$ & 35 & $5.84^{\mathrm{a}}$ & 23 & $6.72^{a}$ & 19 \\
\hline Tourism income (\%) & $1.26^{\mathrm{b}}$ & 8 & $36.65^{a, c}$ & 41 & $1.00^{b}$ & 6 \\
\hline Business income (\%) & $0.6^{\mathrm{b}}$ & 5 & $10.88^{\mathrm{a}, \mathrm{c}}$ & 28 & $1.44^{\mathrm{b}}$ & 9 \\
\hline Other local non-farm income (\%) & $18.03^{b, c}$ & 32 & $8.34^{\mathrm{a}}$ & 19 & $5.52^{\mathrm{a}}$ & 16 \\
\hline Remittance income (\%) & $2.56^{\mathrm{c}}$ & 9 & $1.44^{\mathrm{c}}$ & 8 & $51.16^{a, b}$ & 35 \\
\hline Total incomes (Yuan RMB) & $14,585.43^{b, c}$ & $17,624.24$ & $46,628.87^{a, c}$ & $55,738.90$ & $36,116.53^{a, b}$ & $41,206.64$ \\
\hline
\end{tabular}

The superscript letters indicate categories that are significantly different at the $5 \%$ level to other livelihood type $i$.

\subsection{Livelihood Capital of Different Livelihood Strategies}

Households following different types of livelihood strategies had significantly different characteristics in livelihood capitals. Compared with households mainly engaged in farming, off-farm households had significantly lower natural capitals and significantly higher education levels of household laborers as well as physical capitals, social capitals, and financial capitals. Labor-migrant households had significantly lower natural capital and average age of household laborers, and significantly higher household sizes (Table 3). In comparison to local off-farm households, labor-migrant households had significantly lower education levels, as well as lower physical, social, and financial capitals.

Table 3. Descriptive statistics of livelihood capitals by livelihood strategy.

\begin{tabular}{|c|c|c|c|c|c|c|c|c|}
\hline \multirow{4}{*}{ Livelihood Capital Variables } & \multicolumn{6}{|c|}{ Livelihood Strategy } & \multirow{3}{*}{\multicolumn{2}{|c|}{ Average $(N=756)$}} \\
\hline & \multirow{2}{*}{\multicolumn{2}{|c|}{$\begin{array}{c}\text { a. Farming } \\
(N=429)\end{array}$}} & \multirow{2}{*}{\multicolumn{2}{|c|}{$\begin{array}{c}\text { b. Local Off-Farm } \\
(N=99)\end{array}$}} & \multirow{2}{*}{\multicolumn{2}{|c|}{$\begin{array}{l}\text { c. Labor-Migrant } \\
\qquad(N=228)\end{array}$}} & & \\
\hline & & & & & & & & \\
\hline & Mean & SD & Mean & SD & Mean & SD & Mean & SD \\
\hline \multicolumn{9}{|l|}{ Natural capital } \\
\hline Land area per capita & $4.8^{\mathrm{b}, \mathrm{c}}$ & 10.6 & $1.90^{\mathrm{a}}$ & 4.3 & $2.4^{\mathrm{a}}$ & 3.8 & 3.7 & 8.5 \\
\hline \multicolumn{9}{|l|}{ Human capital } \\
\hline Household size & $3.1^{c}$ & 1.4 & 3.35 & 1.6 & $3.6^{\mathrm{a}}$ & 1.4 & 3.3 & 1.4 \\
\hline Number of household laborers & 2.2 & 0.9 & 2.3 & 1.3 & 2.3 & 1.2 & 2.2 & 1.1 \\
\hline Average education level of household laborers & $2.4^{\mathrm{b}}$ & 0.9 & $2.87^{\mathrm{a}, \mathrm{c}}$ & 1.1 & $2.5^{\mathrm{b}}$ & 0.9 & 2.5 & 1.0 \\
\hline Average age of household laborers & $53.6^{\mathrm{c}}$ & 10.9 & 52.6 & 13.6 & $50.5^{\mathrm{a}}$ & 12.9 & 52.5 & 12.0 \\
\hline \multicolumn{9}{|l|}{ Physical capital } \\
\hline House value & $11.0^{\mathrm{b}}$ & 27.3 & $59.3^{a, c}$ & 109.6 & $11.1^{\mathrm{b}}$ & 21.5 & 17.3 & 48.9 \\
\hline Quantity of household durable & $8.9^{\mathrm{b}}$ & 4.5 & $12.7^{\text {a.c }}$ & 7.7 & $9.31^{\mathrm{b}}$ & 4.2 & 9.5 & 5.1 \\
\hline \multicolumn{9}{|l|}{ Social capital } \\
\hline Social relation & 0.1 & 0.4 & $0.2^{c}$ & 1.5 & $0.1^{\mathrm{b}}$ & 0.3 & 0.1 & 0.4 \\
\hline Communication cost & $81.6^{\mathrm{b}}$ & 89.2 & $189.0^{a, c}$ & 376.1 & $102.2^{b}$ & 106.5 & 101.9 & 165.8 \\
\hline Expense of cash and gifts & $2549.1^{b}$ & 5812.1 & $4006.1^{\mathrm{a}}$ & 5297.6 & 2838.5 & 4416.2 & 2827.2 & 5374.2 \\
\hline \multicolumn{9}{|l|}{ Financial capital } \\
\hline Saving & $0.2^{\mathrm{b}}$ & 0.4 & $0.3^{\mathrm{a}, \mathrm{c}}$ & 0.5 & $0.2^{b}$ & 0.4 & 0.2 & 0.4 \\
\hline Loan & 0.1 & 0.3 & 0.1 & 0.3 & 0.1 & 0.4 & 0.1 & 0.3 \\
\hline Ecological compensation funds & $1774.9^{b}$ & 2816.0 & $3031.7^{\mathrm{a}, \mathrm{c}}$ & 5408.1 & $1408.3^{b}$ & 2336.4 & 1828.9 & 3190.3 \\
\hline
\end{tabular}

The superscript letters indicate categories that are significantly different at the $5 \%$ level to other livelihood type $i$. The definitions of the variables are listed in the Appendix A. 


\subsection{Factors that Influence Livelihood Strategy Choices}

Geographical location, natural capital, household structure, quality of labor force, and ecological policy were the main factors affecting farmers' choices of livelihood strategies. Households that followed a farming livelihood strategy had significantly higher natural capitals than that of other farmers (Table 3). Owing to a greater demand for agricultural labor force, they are more likely to choose farming as their main livelihood strategy.

Table 4 shows factors that are associated with different livelihood strategies compared against predominantly farming strategies. Compared with farming households, shorter distances from the city, less natural capital, higher quality of household laborers, and higher ecological compensation funds were the main factors that promoted farmers to choose local off-farm livelihood strategies. Less natural capital and larger family size are the major contributors to making farmers migrate out for work (Table 4) relative to farming strategies. In addition, we found that the closer farmers lived to Beijing or their local county seat, the higher the rate of off-farm employment. A major reason for this is a reduction in transportation costs that have come with urbanization, which has enhanced local tourism and business, and proximity to the city market access leads to greater off-farm employment opportunities [31].

Table 4. Determinants of different livelihood strategies.

\begin{tabular}{ccccc}
\hline \multirow{2}{*}{ Explanatory Variables } & \multicolumn{2}{c}{ Local Off-Farm } & \multicolumn{2}{c}{ Labor-Migrant } \\
\cline { 2 - 5 } & Coefficient & SE & Coefficient & SE \\
\hline Geographical location & & & & \\
\hline Distance from Beijing city & $-0.01461^{* * *}$ & 0.00371 & 0.00169 & 0.00279 \\
Distance from local county capital city & $-0.02454^{* * *}$ & 0.00723 & -0.00534 & 0.00548 \\
\hline Natural capital & & & \\
\hline Land areas & $-0.03740^{* * *}$ & 0.01032 & $-0.03731^{* * *}$ & 0.00879 \\
\hline Household structure & & & \\
\hline Household size & 0.15346 & 0.10209 & $0.18320^{* *}$ & 0.06893 \\
Average age of household laborers & 0.02463 & 0.01350 & -0.00973 & 0.00923 \\
\hline Human capital $\quad$ & & & \\
\hline Average education level of household laborers & $0.28902 *$ & 0.14607 & -0.03388 & 0.10838 \\
$\quad$ Skill & $0.43586^{* *}$ & 0.13994 & 0.17142 & 0.10683 \\
Training & 0.43131 & 0.45926 & -0.62113 & 0.43857 \\
\hline Ecological policies & & & & \\
\hline Ecological compensation funds & $0.00012^{* *}$ & 0.00004 & -0.00001 & 0.00004 \\
Intercept & -1.21482 & 1.25675 & -0.39628 & 0.93396 \\
\hline
\end{tabular}

Pseudo $R^{2}$ : McFadden = 0.184; Nagelkerke $=0.216$; Cox and Snell $=0.107$. Reference category is farming. $* * *, * *, *$ Indicate statistical significance at the $1 \%, 5 \%$, and $10 \%$ levels, respectively.

\subsection{Livelihood Consequences of Different Livelihood Strategies}

Livelihood strategies differ for different groups of households based on the contextual conditions outlined above, and households following different livelihood strategies may have different livelihood consequences. There are significant differences between farming households and the other two household groups in economic incomes, with local off-farm and labor-migrant households in general having higher income per capita than farming households. Thus, non-agricultural work appears to improve well-being for households. Farming and labor-migrant households have a higher intensity land utilization than local off-farm households, which reflected in crop yield and expense of fertilizer and pesticides. In terms of energy consumption, farming households use significantly higher levels of firewood than local off-farm households, and there is no difference with labor-migrant households. In addition, compared with farming and labor-migrant households, local off-farm households have 
significantly lower fertilizer and pesticide expenses, and significantly higher consumption of total energy, made up of fossil energy and electricity (Table 5).

Table 5. Main livelihood consequences of different livelihood strategies.

\begin{tabular}{|c|c|c|c|c|c|c|c|c|}
\hline \multirow{4}{*}{ Variable } & \multicolumn{6}{|c|}{ Livelihood Strategy } & \multirow{3}{*}{\multicolumn{2}{|c|}{ Average $(N=756)$}} \\
\hline & \multirow{2}{*}{\multicolumn{2}{|c|}{$\begin{array}{l}\text { a. Farming } \\
(N=429)\end{array}$}} & \multirow{2}{*}{\multicolumn{2}{|c|}{$\begin{array}{c}\text { b. Local Off-Farm } \\
(N=99)\end{array}$}} & \multirow{2}{*}{\multicolumn{2}{|c|}{$\begin{array}{c}\text { c. Labor-Migrant } \\
(N=228)\end{array}$}} & & \\
\hline & & & & & & & & \\
\hline & Mean & SD & Mean & SD & Mean & SD & Mean & SD \\
\hline \multicolumn{9}{|l|}{ Economic income } \\
\hline Income per capita & $4939.0^{\mathrm{b}, \mathrm{c}}$ & 5598.2 & $15,029.8^{\mathrm{a}}$ & $18,664.5$ & $11,647.2^{\mathrm{a}}$ & $16,181.4$ & 8283.5 & $12,547.9$ \\
\hline \multicolumn{9}{|c|}{ Land resource development and investment } \\
\hline Crop yield per mu & $322.8^{\mathrm{b}}$ & 198.0 & $133.9^{a, c}$ & 184.5 & $320.1^{\mathrm{b}}$ & 200.7 & 297.3 & 206.8 \\
\hline Expense of fertilizer & $963.9^{b, c}$ & 2171.4 & $139.9^{\mathrm{a}}$ & 276.4 & $540.9^{\mathrm{a}, \mathrm{b}}$ & 612.9 & 728.4 & 1698.0 \\
\hline Expense of pesticide & $186.5^{\mathrm{b}, \mathrm{c}}$ & 217.0 & $36.4^{\mathrm{a}, \mathrm{c}}$ & 100.4 & $112.8^{\mathrm{a}, \mathrm{b}}$ & 148.5 & 144.6 & 193.6 \\
\hline \multicolumn{9}{|l|}{ Firewood consumption } \\
\hline Consumption of firewood & $2615.4^{\mathrm{b}}$ & 2061.4 & $2021.7^{\mathrm{a}}$ & 2031.1 & 2334.2 & 2466.4 & 2452.9 & 2194.7 \\
\hline \multicolumn{9}{|l|}{ Fossil energy consumption } \\
\hline Consumption of coal & $987.1^{\mathrm{b}}$ & 1130.8 & $1852.5^{a, c}$ & 3568.24 & $1066.7^{\mathrm{b}}$ & 1066.5 & 1124.4 & 1673.6 \\
\hline Consumption of LPG & $38.6^{\mathrm{b}}$ & 47.5 & $127.5^{\mathrm{a}, \mathrm{c}}$ & 204.2 & $52.3^{\mathrm{b}}$ & 96.7 & 54.4 & 101.7 \\
\hline \multicolumn{9}{|l|}{ Power consumption } \\
\hline Consumption of electricity & $1089.6^{\mathrm{b}}$ & 1031.9 & $3242.6^{a, c}$ & 4231.6 & $1192.0^{\mathrm{b}}$ & 1187.2 & 1402.4 & 1965.9 \\
\hline Total energy consumption & $2398.6^{b}$ & 1426.3 & $3083.8^{a, c}$ & 3100.5 & $2329.7^{b}$ & 1568.5 & 2467.5 & 1788.6 \\
\hline
\end{tabular}

\section{Discussion}

Against the backdrop of rural-urban transformation in China, great changes have taken place in the rural human-environment relationships, and the choices of household livelihood strategies have become more diversified [32-34]. In this article, local households can be grouped into three types that pursue similar livelihood strategies, specifically, farming, local off-farm, and labor-migrant. Although the households chose local off-farm strategies relatively less often, their livelihood level, impact factors, and livelihood consequences are significantly different from those of the other two types of households. Households following different livelihood strategies hold widely different asset endowments. In our research, the choice of household livelihood strategy was strongly related to geographical location (such as the distance from the nearest market), natural capital, household structure, and ecological policies. It is helpful for managers and policy makers to develop appropriate policies and programs according to different types of livelihood strategies and characteristics. Appropriate management can promote the improvement of peasant household welfare and facilitate more sustainable development in these areas.

Households that engaged in the local non-farm livelihood strategies were able to earn higher incomes. Previous research on rural poverty reduction has also shown that alternative livelihoods have important implications for alleviating poverty as well as furthering conservation objectives in rural areas [7,35]. However, farming households tend to fail to engage in other livelihood activities, particularly in non-farm/commercial strategies, due to limitations of labor quality (education level, skills), financial capital, geographical location, and other factors. Decision-makers should increase non-agriculture employment skills training and provide vocational guidance to those in the agricultural labor force who would like to get non-agricultural employment or work in town. Meanwhile, we also found that high ecological compensation has a direct positive effect on the choice of local off-farm livelihood strategies, and, therefore, decision-makers should provide more eco-compensation to farmers, especially those in poor and remote areas, for improving household financial capital. In addition, many studies have shown that non-farm activities are relatively rare in remote rural areas 
due to poor transport infrastructure and a shortage of skills [7,11]. We also found that nearer to the urban centers and towns, there were greater off-farm employment opportunities. Thus, improving road infrastructure and transport services may help stimulate a part of the agricultural labor force to transfer to the non-agricultural sector, which may also help in alleviating poverty and increasing resilience [24,25].

Different livelihood strategies not only affect the welfare level of households, but non-farm employment and rural-to-urban labor migration can more generally lead to lower dependency on agriculture and local natural resources.

First, our study found that the farming households were more likely to rely on firewood for cooking and heating, as has been found in earlier work in the same region [36]. This can cause substantial, long-term impacts on the local environment, such as deforestation and soil erosion [37-39]. However, local off-farm households were found to have significantly higher total consumption of commercial energy amongst the three household types identified in our study. Commercial energy such as electricity and liquefied gas are available in rural areas and can substitute firewood use, however, due to the low incomes in these areas, especially for farming households, there remains a reluctance to buy commercial energy, and many rural residents still spend time in firewood collection. These findings indicate that the decision-makers need to attach importance to energy structure change for ecological restoration in the countryside. Policies that facilitate the development of alternative energy use, such as providing a discount for commercial energy, particularly for farming households, could substantially reduce the consumption of firewood.

Second, some evidence has shown that farming households tend to increase crop yields through heavy input of pesticides and fertilizers [40]. This mode of modern agriculture also brings with it a series of adverse environmental impacts [41]. Ecological agriculture programs and conservation-oriented training programs, concentrating on basic scientific and technological research, should be provided free to farmers who participate in ecological agriculture.

Third, we found that local off-farm households have the lowest land use efficiency and a large amount of agricultural land around them is abandoned. Because this abandonment of arable land results from changes in livelihood activities, the government should make vigorous efforts to restructure the management of natural resources to achieve the goal of rural development and ecological protection. For example, giving subsidies to farmers to convert abandoned cultivated land into economic forests, providing incentives to increase the scale of agricultural operations, and encouraging agricultural land transfers, among other policies, should be implemented [42,43].

Finally, non-farm employment and labor migration increase dependency on the general economy and job market. Meanwhile, the farm is still managed by a portion of the household and can act as a "backup" household livelihood strategy, which helps increase overall household resilience.

Our study focuses only on the Miyun Reservoir watershed, and does not include the outside overflow of environmental impacts of migration [44]. For example, migrant workers move out from rural areas for employment, which can reduce the population carrying capacity on the local ecological environment and provide the most basic conditions for ecological restoration. However, on a regional scale, whether this shift of part of the labor force from rural to urban areas increases the pressure on urban environments is unknown. Therefore, we still need more information regarding the large-scale effects caused by changes in household livelihood strategies; carrying out comprehensive assessments and considering sustainable development goals from multiple dimensions will be necessary in the future.

In conclusion, we identified livelihood strategies by clustering households based on the share of household income generated by different livelihood activities and the ability of household members to migrate for work. The variables we include in the cluster analysis are total income, agricultural income, tourism income, agri-business income, other local non-farm income, remittance income, and moving out for work. Then we provide tailored policy and management options to promote sustainable livelihoods based on our findings. Our study could be of great value and serve as a reference for 
further analyses of rural household livelihood characteristics, as well as provide a basis for managing the sustainable utilization of natural resources and poverty reduction at the watershed scale.

Acknowledgments: We thank the National Natural Science Foundation of China (41371538, 71673219), National Key Research and Development Program of China (No. 2016YFC0503401), and the Canadian Social Science and Humanities Research Council (No. 430-2014-00861) for support.

Author Contributions: Hua Zheng and Brian E. Robinson conceived and designed this study, Wenjia Peng, Hua Zheng, Brian E. Robinson, Fengchun Wang and Cong Li participated in the field survey; Wenjia Peng analyzed the data and wrote the manuscript, Hua Zheng, Brian E. Robinson and Cong Li revised the manuscript. All authors read and approved the manuscript.

Conflicts of Interest: The authors declare no conflict of interest.

\section{Appendix A. Explanatory Variable Definition}

Table A1. The definition of explanatory variable in this paper.

\begin{tabular}{|c|c|c|}
\hline Explanatory Variables & Unit & Definition \\
\hline \multicolumn{3}{|l|}{ Natural capital } \\
\hline Land area per capita & $\mathrm{mu}$ & Average land area (in mu) per capita in each household \\
\hline Land area & $\mathrm{mu}$ & Total land area of each household 1 \\
\hline \multicolumn{3}{|l|}{ Human capital } \\
\hline Household size & capita & Number of household members \\
\hline Number of household laborers & capita & Number of household laborers \\
\hline $\begin{array}{c}\text { Average education level of household } \\
\text { laborers }\end{array}$ & Dummy variable & $\begin{array}{c}\text { Illiteracy }=1 \text {; Primary school }=2 \text {; Junior high school = } 3 ; \\
\text { Senior high school }=4 ; \text { Technical secondary school }=5 ; \\
\text { Bachelor degree or above }=6\end{array}$ \\
\hline Average age of household laborers & year & Average age of household laborers \\
\hline Training & Dummy variable & Receiving job training $=1$ \\
\hline Skill & Dummy variable & Mastering some skill = 1 \\
\hline \multicolumn{3}{|l|}{ Physical capital } \\
\hline House value & yuan & Market value of the house \\
\hline Quantity of household durable & - & $\begin{array}{c}\text { Total number of household durables, including mobile } \\
\text { phone, air condition, refrigerator, television, tractor, } \\
\text { bicycle, motorcycle, car, electric cooker, washing } \\
\text { machine, etc. }\end{array}$ \\
\hline \multicolumn{3}{|l|}{ Social capital } \\
\hline Social relation & capita & Number of cadres in household members \\
\hline Communication cost & yuan/year & Communication cost in each household \\
\hline Expense of cash and gifts & yuan/year & Total cash and gifts in each household \\
\hline \multicolumn{3}{|l|}{ Financial capital } \\
\hline Saving & Dummy variable & Have savings $=1$ \\
\hline Loan & Dummy variable & Borrowing money from friends and relatives or bank $=1$ \\
\hline Ecological compensation funds & yuan/year & $\begin{array}{l}\text { Ecological compensation funds from government } \\
\text { per year per household }\end{array}$ \\
\hline \multicolumn{3}{|l|}{ Others } \\
\hline Income per capita & yuan/year & Average income per capita last year \\
\hline Crop yield per mu & $\mathrm{kg} / \mathrm{mu} /$ year & Average crop yield per mu last year \\
\hline Expense of fertilizer & yuan/year & Fertilizer expense per household last year \\
\hline Expense of pesticide & yuan/year & Pesticide expense per household last year \\
\hline Consumption of firewood & $\mathrm{kg} /$ year & Firewood consumption of per household last year \\
\hline Consumption of coal & $\mathrm{kg} /$ year & Coal consumption per household last year \\
\hline Consumption of LPG & $\mathrm{kg} /$ year & $\begin{array}{l}\text { LPG (liquefied petroleum gas) consumption per } \\
\text { household last year }\end{array}$ \\
\hline Consumption of electricity & kwh/year & Electricity Consumption per household last year \\
\hline Total energy consumption & tce & Total energy consumption per household last year \\
\hline Distance from Beijing city & $\mathrm{km}$ & Distance from the Beijing city \\
\hline Distance from local county capital city & $\mathrm{km}$ & Distance from local county capital city \\
\hline
\end{tabular}




\section{References}

1. Scoones, I. Livelihoods perspectives and rural development. J. Peasant Stud. 2009, 36, 171-196. [CrossRef]

2. Li, B.; Li, X.Y.; Zuo, T. Research and Practice on Means of Livelihood in Rural Development. J. Agrotech. Econ. 2004, 4, 10-15. (In Chinese)

3. Qin, H.; Flint, C.G. Integrating Rural Livelihoods and Community Interaction into Migration and Environment Research: A Conceptual Framework of Rural Out-Migration and the Environment in Developing Countries. Soc. Nat. Resour. 2012, 25, 1056-1065. [CrossRef]

4. Salafsky, N.; Wollenberg, E. Linking livelihoods and conservation: A conceptual framework and scale for assessing the integration of human needs and biodiversity. World Dev. 2000, 28, 1421-1438. [CrossRef]

5. Ellis, F. Household strategies and rural livelihood diversification. J. Dev. Stud. 1998, 35, 1-38. [CrossRef]

6. Wang, C.; Yang, Y.; Zhang, Y. Rural household livelihood change, fuelwood substitution, and hilly ecosystem restoration: Evidence from China. Renew. Sustain. Energy Rev. 2012, 16, 2475-2482. [CrossRef]

7. Alemu, Z.G. Livelihood strategies in rural South Africa: Implications for poverty reduction. In Proceedings of the 2012 Conference on International Association of Agricultural Economists, Foz do Iguacu, Brazil, 18-24 August 2012.

8. Ellis, F.; Mdoe, N. Livelihoods and rural poverty reduction in Tanzania. World Dev. 2003, 31, 1367-1384. [CrossRef]

9. Soltani, A.; Angelsen, A.; Eid, T.; Naieni, M.S.N.; Shamekhi, T. Poverty, sustainability, and household livelihood strategies in Zagros, Iran. Ecol. Econ. 2012, 79, 60-70. [CrossRef]

10. Brown, D.R.; Stephens, E.C.; Ouma, J.O.; Murithi, F.M.; Barrett, C.B. Livelihood Strategies in the Rural Kenyan Highlands; Cornell University: Ithaca, NY, USA, 2006.

11. Jansen, H.G.; Pender, J.; Damon, A.; Wielemaker, W.; Schipper, R. Policies for sustainable development in the hillside areas of Honduras: A quantitative livelihoods approach. Agric. Econ. 2006, 34, 141-153. [CrossRef]

12. Leo, D.H.; Annelies, Z. Exploring the frontier of livelihood research. Dev. Chang. 2005, 36, $27-47$.

13. Bebbington, A. Capitals and capabilities: A framework for analyzing peasant viability, rural livelihoods and poverty. World Dev. 1999, 27, 2021-2044. [CrossRef]

14. Bury, J. Livelihoods in transition: Transnational gold mining operations and local change in Cajamarca, Peru. Geogr. J. 2004, 170, 78-91. [CrossRef]

15. Scoones, I. Sustainable Rural Livelihoods: A Framework for Analysis; IDS: Brighton, UK, 1998.

16. Leach, M.; Mearns, R.; Scoones, I. Environmental entitlements: Dynamics and institutions in community-based natural resource management. World Dev. 1999, 27, 225-247. [CrossRef]

17. Ribot, J.C.; Peluso, N.L. A theory of access. Rural Sociol. 2003, 68, 153-181. [CrossRef]

18. Schoenberger, L.; Turner, S. Negotiating Remote Borderland Access: Small-Scale Trade on the Vietnam-China Border. Dev. Chang. 2008, 39, 667-696. [CrossRef]

19. Ellis, F. The determinants of rural livelihood diversification in developing countries. J. Agric. Econ. 2000, 51, 289-302. [CrossRef]

20. Binder, C.R.; Hinkel, J.; Bots, P.W.G.; Pahl-Wostl, C. Comparison of Frameworks for Analyzing Social-ecological Systems. Ecol. Soc. 2013, 18, 26. [CrossRef]

21. Department for International Development. Sustainable Livelihoods Guidance Sheets; Department for International Development: London, UK, 2000.

22. Little, P.D.; Smith, K.; Cellarius, B.A.; Coppock, D.L.; Barrett, C. Avoiding Disaster: Diversification and Risk Management among East African Herders. Dev. Chang. 2001, 32, 401-433. [CrossRef]

23. Reardon, T.; Berdegué, J.; Escobar, G. Rural Nonfarm Employment and Incomes in Latin America: Overview and Policy Implications. World Dev. 2001, 29, 395-409. [CrossRef]

24. Huber, F.K.; Morlok, M.; Weckerle, C.S.; Seeland, K. Livelihood strategies in Shaxi, Southwest China: Conceptualizing mountain-valley interactions as a human-environment system. Sustainability 2015, 3204-3229. [CrossRef]

25. Démurger, S.; Fournier, M.; Yang, W. Rural households' decisions towards income diversification: Evidence from a township in northern China. China Econ. Rev. 2010, 21 (Suppl. S1), S32-S44. [CrossRef]

26. Renwei, H.E.; Liu, S.; Chen, G.; Xie, F.; Yang, X.; Liang, L. Research progress and tendency of sustainable livelihoods for peasant household in China. Prog. Geogr. 2013, 32, 657-670. 
27. Liu, J.; Ouyang, Z.; Yang, W.; Xu, W.; Li, S. Evaluation of Ecosystem Service Policies from Biophysical and Social Perspectives: The Case of China. In Encyclopedia of Biodiversity, 2nd. ed.; Academic Press: Waltham, MA, USA, 2013; pp. 372-384.

28. Uchida, E.; Rozelle, S.; Xu, J. Conservation payments, liquidity constraints and off-farm labor: Impact of the Grain for Green program on rural households in China. In An Integrated Assessment of China's Ecological Restoration Programs; Springer: Berlin, Germany, 2009; pp. 131-157.

29. Zhen, N.; Fu, B.; Lü, Y.; Zheng, Z. Changes of livelihood due to land use shifts: A case study of Yanchang County in the Loess Plateau of China. Land Use Policy 2014, 40, 28-35. [CrossRef]

30. Zheng, H.; Robinson, B.E.; Liang, Y.-C.; Polasky, S.; Ma, D.-C.; Wang, F.-C.; Ruckelshaus, M.; Ouyang, Z.-Y.; Daily, G.C. Benefits, costs, and livelihood implications of a regional payment for ecosystem service program. Proc. Natl. Acad. Sci. USA 2013, 110, 16681-16686. [CrossRef] [PubMed]

31. Pachauri, S.; Spreng, D. Towards an Integrative Framework for Energy Transitions of Households in Developing Countries; Springer: Dordrecht, The Netherlands, 2012; pp. 73-96.

32. Huang, J. The effect of off-farm employment on the decisions of households to rent out and rent in cultivated land in China. China Agric. Econ. Rev. 2012, 4, 5-17. [CrossRef]

33. Huber, F.K.; Yang, Y.; Weckerle, C.S.; Seeland, K. Diversification of Livelihoods in a Society in Transition: A Case Study of Tibetan Communities in Southwest China. Soc. Nat. Resour. 2014, 27, 706-723. [CrossRef]

34. Zhang, F.F.; Zhao, X.Y. A review of ecological effect of peasant's livelihood transformation in China. Acta Ecol. Sin. 2015, 35, 3157-3164. (In Chinese) [CrossRef]

35. Wang, C.; Yang, Y. Review of research on mountains ecological restoration based on farmer household livelihood evolution. J. Nat. Resour. 2011, 26, 344-352. (In Chinese)

36. Démurger, S.; Fournier, M. Poverty and firewood consumption: A case study of rural households in northern China. China Econ. Rev. 2011, 22, 512-523. [CrossRef]

37. Chen, X.; Frank, K.A.; Dietz, T.; Liu, J. Weak Ties, Labor Migration, and Environmental Impacts: Toward a Sociology of Sustainability. Organ. Environ. 2012, 25, 3-24. [CrossRef]

38. Liu, G.; Lucas, M.; Shen, L. Rural household energy consumption and its impacts on eco-environment in Tibet: Taking Taktse county as an example. Renew. Sustain. Energy Rev. 2008, 12, 1890-1908. [CrossRef]

39. Feng, W.L.; Li, S.Z.; Li, C. Overview and Frame Work for Ecosystem Services and Human Well-being. Resour. Sci. 2013, 35, 1482-1489. (In Chinese)

40. Mclaughlin, D.; Kinzelbach, W. Food security and sustainable resource management. Water Resour. Res. 2015, 51, 4966-4985. [CrossRef]

41. Li, W.H.; Liu, M.C.; Min, Q.W. China's Ecological Agriculture: Progress and Perspectives. J. Resour. Ecol. 2010, 6, 1015-1021. (In Chinese)

42. Ding, C. Land policy reform in China: Assessment and prospects. Land Use Policy 2003, 20, 109-120. [CrossRef]

43. Lichtenberg, E.; Ding, C. Chapter 5: Assessing Farmland Protection Policy in China. Urban. China Crit. Issues Era Rapid Growth 2007, 25, 59-68.

44. Liu, J.; Hull, V.; Luo, J.; Yang, W.; Liu, W.; Viña, A.; Vogt, C.; Xu, Z.; Yang, H.; Zhang, J. Multiple telecouplings and their complex interrelationships. Ecol. Soc. 2015, 20, 44. [CrossRef]

(C) 2017 by the authors; licensee MDPI, Basel, Switzerland. This article is an open access article distributed under the terms and conditions of the Creative Commons Attribution (CC BY) license (http:/ / creativecommons.org/licenses/by/4.0/). 